\title{
Intersite epibiosis characterization on dominant mangrove crustacean species from Malaysia
}

\author{
Gregorio Fernandez-Leborans ${ }^{1,4}$, Yukio Hanamura ${ }^{2,5}$, Ryon Siow ${ }^{3,6}$, Phaik-Ean Chee ${ }^{3,7}$ \\ ${ }^{1}$ Department of Zoology, Faculty of Biology, Pnta 9, Complutense University, 28040 Madrid, Spain \\ ${ }^{2}$ Japan International Research Center for Agricultural Sciences Owashi 1-1, Tsukuba 305-8686, Japan \\ ${ }^{3}$ Fisheries Research Institute, Batu Maung, 11960, Malaysia \\ ${ }^{4}$ E-mail:greg@bio.ucm.es \\ ${ }^{5}$ E-mail: hanamura@affrc.go.jp \\ ${ }^{6}$ E-mail:ppryon@yahoo.com \\ ${ }^{7}$ E-mail: phaikean@hotmail.com
}

Key words: crustacean basibionts, epibiosis, hyperbenthic fauna, Malaysia mangroves, offshore areas, protozoan epibionts

\begin{abstract}
Epibiosis was studied in dominant mangrove crustacean species in several areas in Malaysia. The observed basibionts were the crustaceans Mesopodopsis orientalis, Acetes japonicus, Acetes sibogae, Acetes indicus and Fenneropenaeus merguiensis and the epibionts found were the protozoan ciliates Acineta branchicola, Lagenophrys eupagurus, Conidophrys pitelkae and Zoothamnium duplicatum. Basibionts from the open sea area (Acetes japonicas) and from a sandy beach of Penang (Mesopodopsis orientalis) showed the lowest epibiont densities. Considering all the colonized anatomical units each basibiont species had a distinct epibiotic distribution and the epibiont species presented a significantly different distribution over each of the basibiont species. In the basibiont M. orientalis a significant difference was observed in epibiotic distribution between populations from different geographical areas. Species sampled on mangrove and offshore areas also differed in this respect The different epibiont species varied among locations according to the structure of the community. We also report on the pattern of epiobiont distribution over the anterioposterior axis of the basibiont, on the influence of physiological characteristics of basibiont and epibiont and on the influence of environmental conditions on the epibiont communities.
\end{abstract}

\section{Contents}

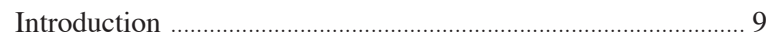

Material and methods ................................................................... 11

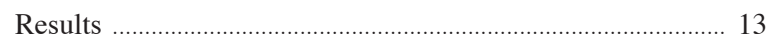

Epibiont species ………………………………………..... 13

Distribution of epibionts ……………………...................... 15

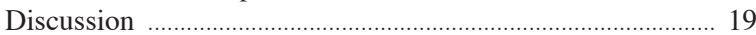

Acknowledgements .................................................................. 21

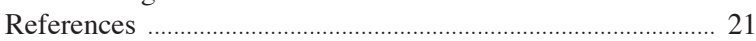

\section{Introduction}

Epibiosis is a facultative association of two organisms: the epibiont and the basibiont (Wahl, 1989). The term epibiont includes organisms that, during the sessile phase of their life cycle, are attached to the surface of a living substratum, while the basibiont lodges and constitutes a support for the epibiont (Threlkeld et al., 1993). Both concepts describe ecological functions (Wahl, 1989). Several crustacean groups such as cladocerans, copepods, cirripedes, isopods, amphipods and decapods include forms that are hosts for macroepibiont invertebrates (Porifera, Cnidaria, Platyhelminthes, Nemertea, Rotifera, Nematoda, Polychaeta, Cirripedia, Decapoda, Gastropoda, Bivalvia, Phoronida, Bryozoa, Ascidiacea and others) (Ross, 1983) and for protozoan microepibionts of the phylum Ciliophora (apostomatids, chonotrichids, suctorians, peritrichs, and heterotrichs) (Corliss, 1979; Small and Lynn, 1985).

The epibiosis involves different aspects, among which: (1) the specificity between epibionts and their crustacean basibionts; (2) the morphological and physiological adaptations of the epibionts; (3) the effects produced by the epibionts on the crustaceans; (4) the possible use of epibionts for the assessment of water quality; (5) the implications of epibionts on cultures of crustaceans and (6) the organization of the epibiont communities. A number of effects are related to epibiosis. These include advantages for the epibiont such as dispersal and geographical expansion, increase of the supply of nutrients and protection against predation 
(Connell and Keough, 1985; Williams and Moyse, 1988; Abelló et al., 1990; Key et al., 1997). On the other hand, epibiosis can be disadvantageous to the epibiont, creating ontogenetic or behavioural changes of the basibiont. Epibiosis can provide mimetic protection for the basibiont and cleaning. Conversely, epibiosis may have the disadvantage of restricting the mobility of the basibiont, it may affect growth and moulting and the functioning of several organs (eyes, gills, appendages, reproductive systems) and it may cause an increase of the risk of predation. Epibionts and basibionts also may compete for nutrients (Wahl, 1989; Threlkeld et al., 1993; Becker and Wahl, 1996).
Epibiotic associations could represent excellent models to examine diversity patterns among geographical regions on a variety of scales, including whole communities of species in different habitats. Although many crustaceans have been studied for their behaviour, few studies dealt with their associates and virtually nothing is known about the interactions between these epibionts and their basibiont hosts (Utz, 2003). The study of physical and biological factors related to the origin of symbioses, hypersymbioses and predatorprey relationships is a promising field of research (Williams and McDermott, 2004).

Many marine sessile life forms depend on the characteristics of the living substratum to which they are

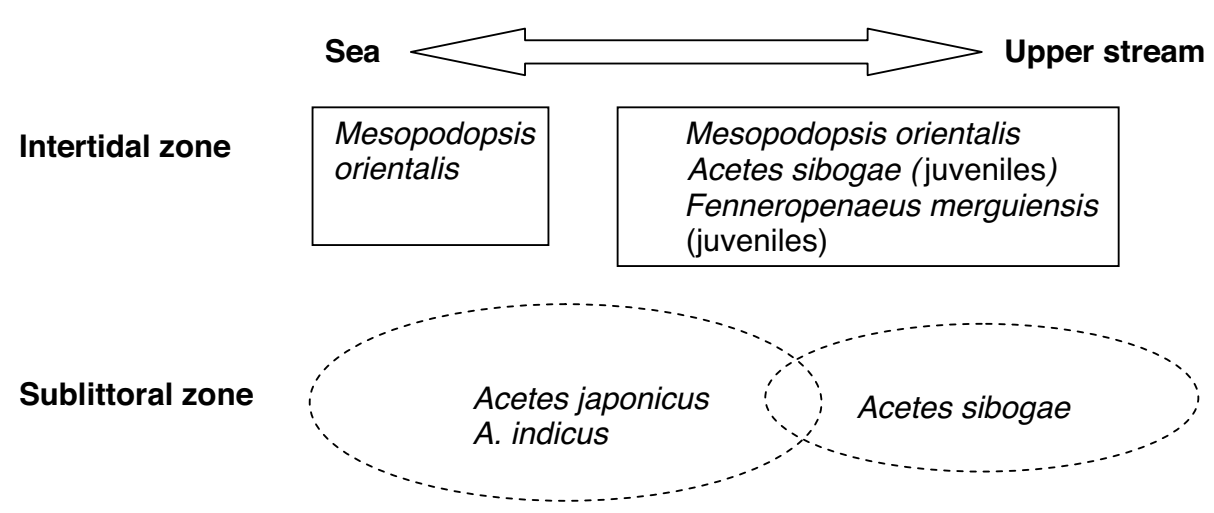

Fig. 1. Distribution of hyperbenthic crustaceans in an estuary system in Peninsular Malaysia (schematic, modified from Hanamura et al., in press b)
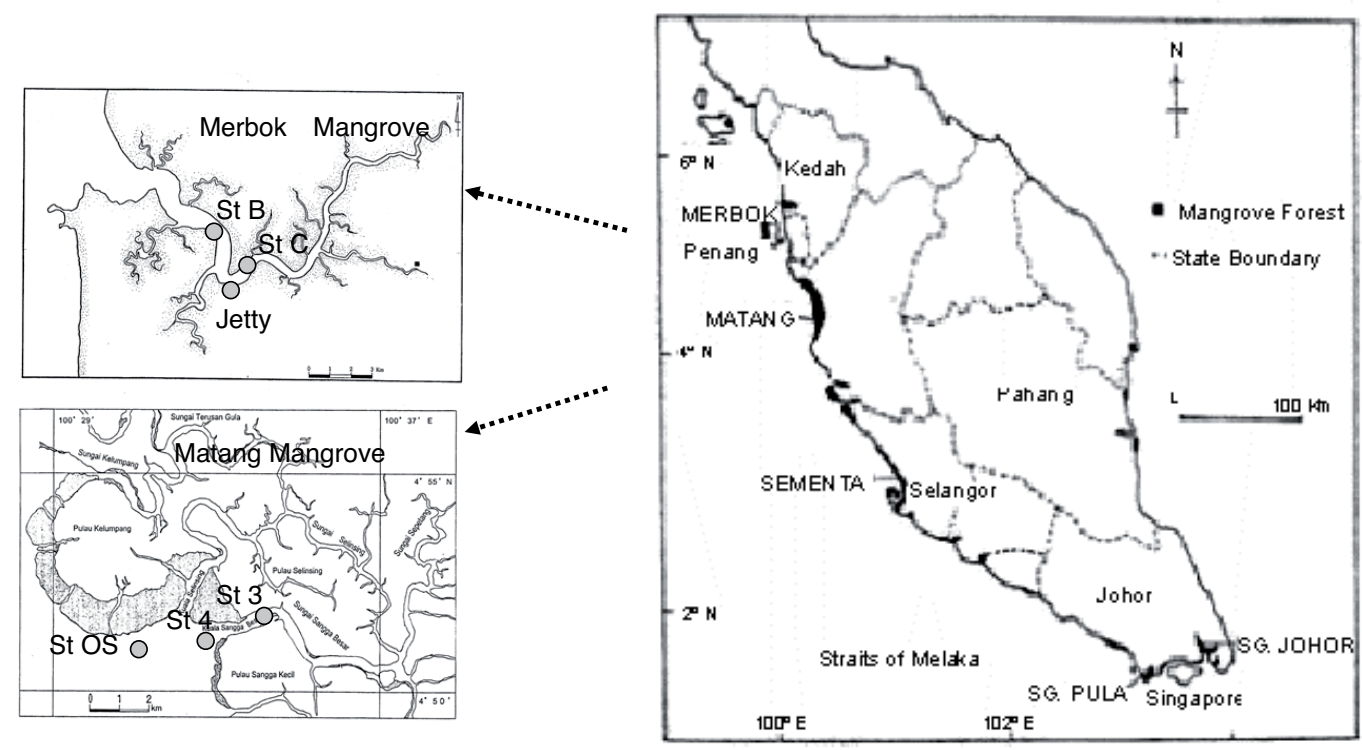

Fig. 2. Study area (right) and sampling sites (left) in north-western peninsular Malaysia. For locality names see text. 
adhered (Gili et al., 1993) and, consequently, structure dynamics, physiology, and ecology of the basibiont may reflect on colonisation patterns of the epibiont species, and on settlement and growth of communities of invertebrates and protists.

Epibiosis is the evolutionary result of the interaction of environmental factors with benthic life forms (Key et al., 1999). It is a dynamic process, and the benefits and disadvantages to the intervening organisms vary depending on environmental conditions (Bush et al., 2001). Epibiosis can appear as a temporal colonisation due to a diminution of basibiont defences (Wahl and Mark, 1999). Epibiosis may modify a number of interactions between the basibiont and biotic and abiotic components of the system. Despite its wide occurrence, epibiosis is still not very well known with respect to its consequences for both basibionts and epibionts. A number of studies of crustacean epibiosis have been performed in freshwater systems, with few focusing on marine and estuarine environments (Carman and Dobbs, 1997). Epibiosis, as one of the closest possible interspecific associations, is a common phenomenon in shallow subtidal communities. Fouling of the basibiont creates a new interface between the basibiont and its environment. Most interactions between a living organism and its biotic and abiotic environment (e.g., predation, mating, defence, mutualism, parasitism, symbiosis, drag) are linked to essential surface features of the organism (Laudien and Wahl, 2004).

Epibiont populations may have relevant functions at the ecosystem level. Epibionts showing high densities may even contribute to energy flow to higher trophic levels. The colonization of a marine hard-bottom community on newly available substrata is governed by presettlement (survival and distribution of colonising stages), settlement (composition of coloniser pool, competence of settling stages, substratum preferences) and post-settlement processes (competition, consumption, etc.). When, during recruitment, substratum becomes the limiting factor, dominant competitors may drive competitively inferior species to extinction (Enderlein and Wahl, 2004). Epibiosis is important with regard to biodiversity and conservation. In temperate regions diversity, or species richness, of benthos in soft substrates on the continental shelf and slope may rival that in shallow tropical seas (Brusca and Brusca, 1990).

In tropical mangrove estuaries and related coastal waters in Malaysia and Thailand several crustacean species occur in abundance, constituting a substantial portion of the hyperbenthic fauna (Hanamura et al., in press $a, b)$. These crustaceans also are major dietary resources of mangrove fishes (e.g., Kiso and Mahyam, 2003; Chew et al., 2006; Then et al., 2006), which suggests that they play an important ecological role in the mangrove estuary.

These species showed a generalized distributional pattern in mangrove systems of north-western Peninsular Malaysia, as is indicated in Fig. 1, where adult and subadult Acetes indicus Milne Edwards 1830 and A. japonicus Kishinouye 1905 occur in abundance in the sublittoral zone of the river mouth, while A. sibogae Hansen 1919 tends to be found in increasing numbers in the middle to upper reaches. In contrast, Mesopodopsis orientalis (Tattersall, 1908) has a strong affinity to the littoral zone from coastal to upstream areas. Meanwhile, there is a possibility of the existence of two populations of $M$. orientalis in the studied areas, i.e., estuarine and coastal populations (Hanamura et al., unpublished data). Consequently, the sampling sites of this mysid are specified for future consideration. Like Mesopodopsis, young juveniles of A. sibogae and Fenneropenaeus merguiensis de Man 1888 occur predominantly along the littoral zone of the estuary swamp (Hanamura et al., in press $a, b)$.

Recent ecological studies on the hyperbenthos have revealed that the ciliate-crustacean association is a frequently observed phenomenon in tropical mangrove estuaries and related coastal waters (Hanamura et al., unpublished data). In the present study, the epibiosis on these crustacean species was analyzed, with emphasis on the differences between basibiont species, and between the diverse sampling sites. The epibiosis was also considered in terms of preference of epibiotic species and with respect to the structure composition of the epibiont community. The purpose of this study is (1) to analyze if the epibiotic communities on the diverse basibiont species and localities present particular characteristics related to the species found, and (2) their distribution on the anatomical units of the basibiont. We will propose explanations for the different patterns of colonization. We hypothesize that dominant mangrove crustacean species present a characteristic epibiosis specific to each species and different from populations living on open sea environments.

\section{Material and methods}

The basibiont species were sampled in areas of Malaysia and Thailand indicated in Fig. 2. The crustaceans listed below were collected as follows:

- Mesopodopsis orientalis or M. orientalis B, Merbok 


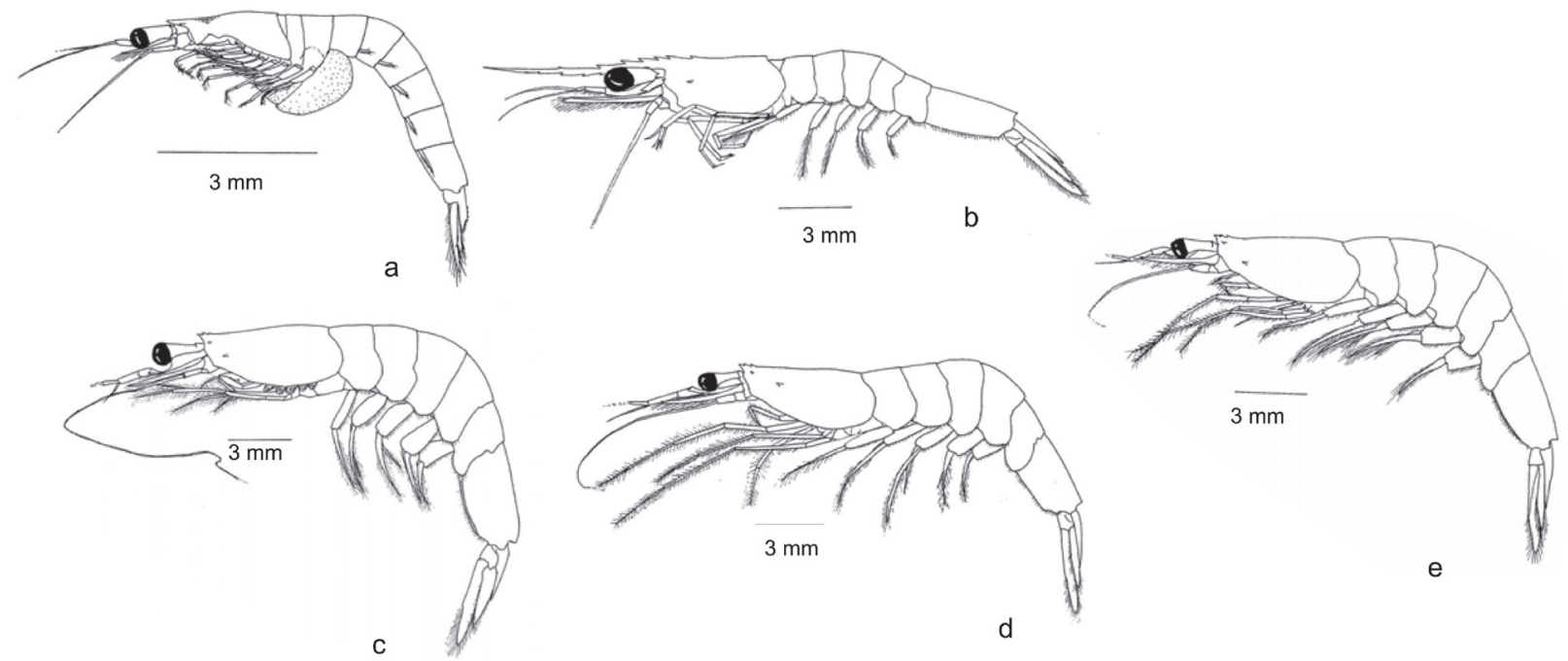

Fig. 3. Basibiont species: a, Mesopodopsis orientalis, adult female; b, Fenneropenaeus merguiensis, juvenile; c, Acetes japonicas, adult female; d, A. indicus, adult female and e, A. sibogae, adult female.

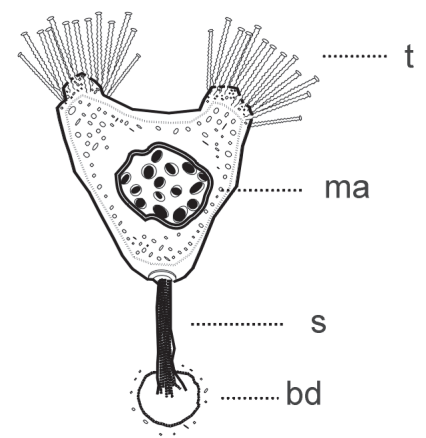

a

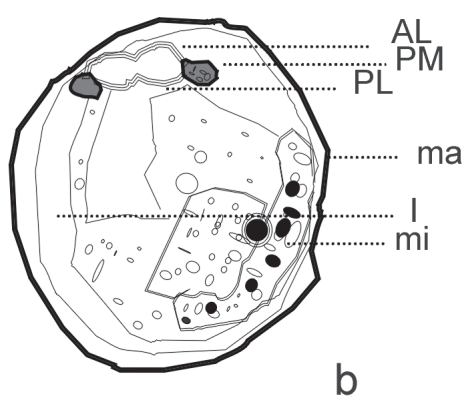

b

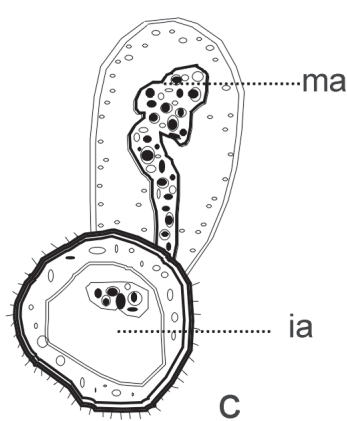

C

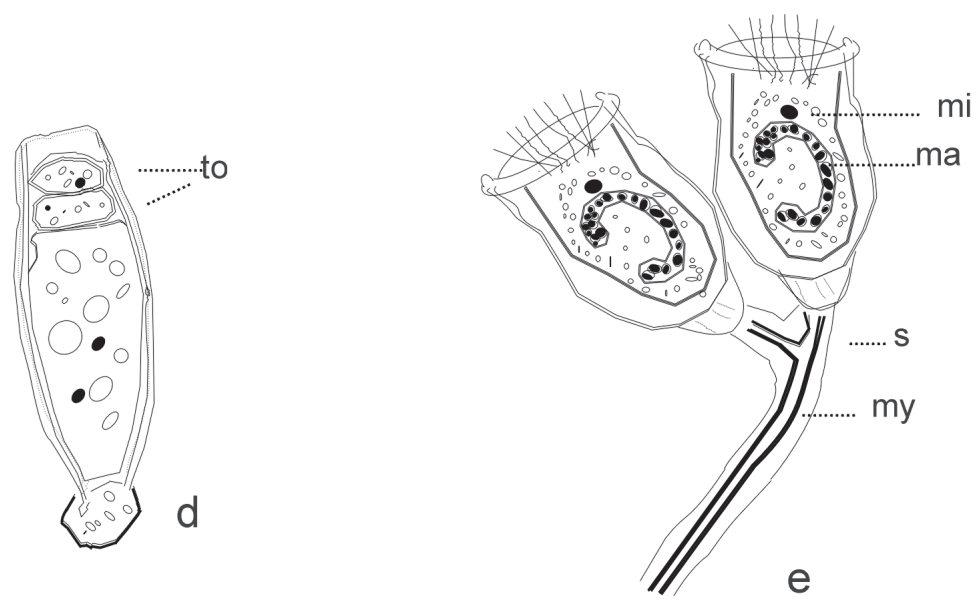

Fig. 4. Epibiont species: a, Acineta tuberose; b, Lagenophrys eupagurus; c, Conidophrys pitelkae, trophont; d, Conidophrys pitelkae, tomont and e, Zoothamnium duplicatum, with ma, macronucleus; mi, micronucleus; bd, basal disc; AL, anterior lip; PL, posterior lip; PM, peristomial myoneme; I, infundibulum; ia, ingestive apparatus; to; tomite; my, myoneme; s, stalk and t, tentacles. 
mangrove, Malaysia, Station B, sandy beach, littoral, hand net, 17.05.2006 $(\mathrm{n}=20)$

- M. orientalis C, Merbok mangrove, Malaysia, Station C, sandy beach, littoral, hand net, 09.12.2004 (n $=20$ )

- M. orientalis M, Merbok mangrove, Malaysia, Kampong Batu-Lintang Jetty, littoral, hand net, 16.12.2005 $(\mathrm{n}=20)$

- M. orientalis OS, coastal water without mangrove, Teluk Kumbar, Penang, Malaysia, sandy beach, littoral, hand net, 16.03.05 $(\mathrm{n}=20)$

- M. orientalis T, Samut Songkhram, Thailand, shrimp culture pond, sublittoral, grab, 13.07.2005 $(\mathrm{n}=20)$

- Acetes japonicus, Matang Mangrove, Malaysia, Stations 3, 4, sledge, sublittoral, 15.12.2005 $(\mathrm{n}=20)$

- A. japonicus OS, coastal water without mangrove, Teluk Kumbar, Penang, Malaysia, sandy beach, littoral, hand net, 18.01.2006 $(\mathrm{n}=20)$

-Acetes sibogae, Matang mangrove, Malaysia, 4 km offshore of Station 4, sledge, sublittoral, 13.06.2006 $(\mathrm{n}=20)$

-Acetes indicus, Matang mangrove, Malaysia, Station 4, sledge, sublittoral, 15.12.2005 $(\mathrm{n}=20)$

- Fenneropenaeus merguiensis, Merbok mangrove, Malaysia, Station C,sandy beach, littoral, hand net, 09.12. $2004(\mathrm{n}=20)$.

The FAO (Food and Agriculture Organization) names of the host crustaceans are $F$. merguiensis (listed as Penaeus merguiensis) - Banana prawn; A. indicus - Jawla paste shrimp; A. japonicus - Akiami paste shrimp and A. sibogae - Alamang shrimp (Carpenter and Niem, 1988) (Fig. 3).

Samples were fixed upon collection in 5\% seawaterbuffered formalin. Water temperature and salinity were measured using an electronic T-S meter (Alec ACT20 D2) (for the actual data see Hanamura et al., in press a, b). Crustaceans were dissected in the laboratory and each relevant anatomical unit was observed under a stereomicroscope. Epibionts on the surface of the anatomical units were counted under stereo- and compound microscopes. The density of colonial species was measured as the number of zooids. In order to identify the protozoan epibionts, they were isolated and treated with the silver carbonate technique of Fernandez-Leborans and Castro de Zaldumbide (1986), and with methyl green and neutral red. Permanent slides were obtained from the stained ciliates. Measurements of the epibionts were taken using an ocular micrometer. Light microscope images were obtained using image analysis (KS300 Zeiss). Taxonomic classification of ciliate spe- cies was made according to Lynn and Small (2000).

Statistical analyses were performed with Statgraphics and SPSS software and included principal component analysis, multiple comparison, multiple regression, MANOVA and hierarchical conglomerate analyses with the Manhattan metric distance.

\section{Results}

\section{Epibiont species}

Epibionts described and analyzed below were found on the following crustacean basibionts, all belonging to the class Malacostraca: Mesopodopsis, orientalis (family Mysidae, order Mysidacea), Acetes japonicus, A. sibogae and A. indicus (family Sergestidae; order Decapoda) and Fenneropenaeus merguiensi (family Penaeidae; order Decapoda).

The epibionts found belong to the following four protozoan ciliate species: Acineta tuberosa, Lagenophrys eupagurus, Conidophrys pitelkae and Zoothamnium duplicatum. Short descriptions are provided below.

phylum Ciliophora Doflein, 1901

class Phyllopharyngea De Puytorac et al., 1974

subclass Suctoria Claparède and Lachmann, 1858

order Endogenida Collin, 1912

family Acinetidae Stein, 1859

genus Acineta Ehrenberg, 1833

Acineta tuberosa Ehrenberg, 1833

(Figs. 4a, 5a).

This loricate suctorian is small- to medium-sized (25$120 \mu \mathrm{m}$ long), bell to Y-shaped, laterally flattened. It presented two actinophores, each with a fascicle of capitate tentacles. The apical aperture is dumb-bell shaped. Cytoplasm does not always completely fill lorica. The stalk is variable in length (5-90 $\mu \mathrm{m}$ long), joining lorica without collar or other structure, usually with basal disc. The reproduction is by endogenous budding. The spherical macronucleus is centrally located. A single contractile vacuole is situated apically. It has been found on a variety of substrata, including crustaceans: species of the shrimp Crangon sp., the isopods Idothea tricuspidata Desmarest, 1823 and Microcerberus remyi Chappuis, 1953 and the amphipod Gammarus locusta (Curds, 1985). 

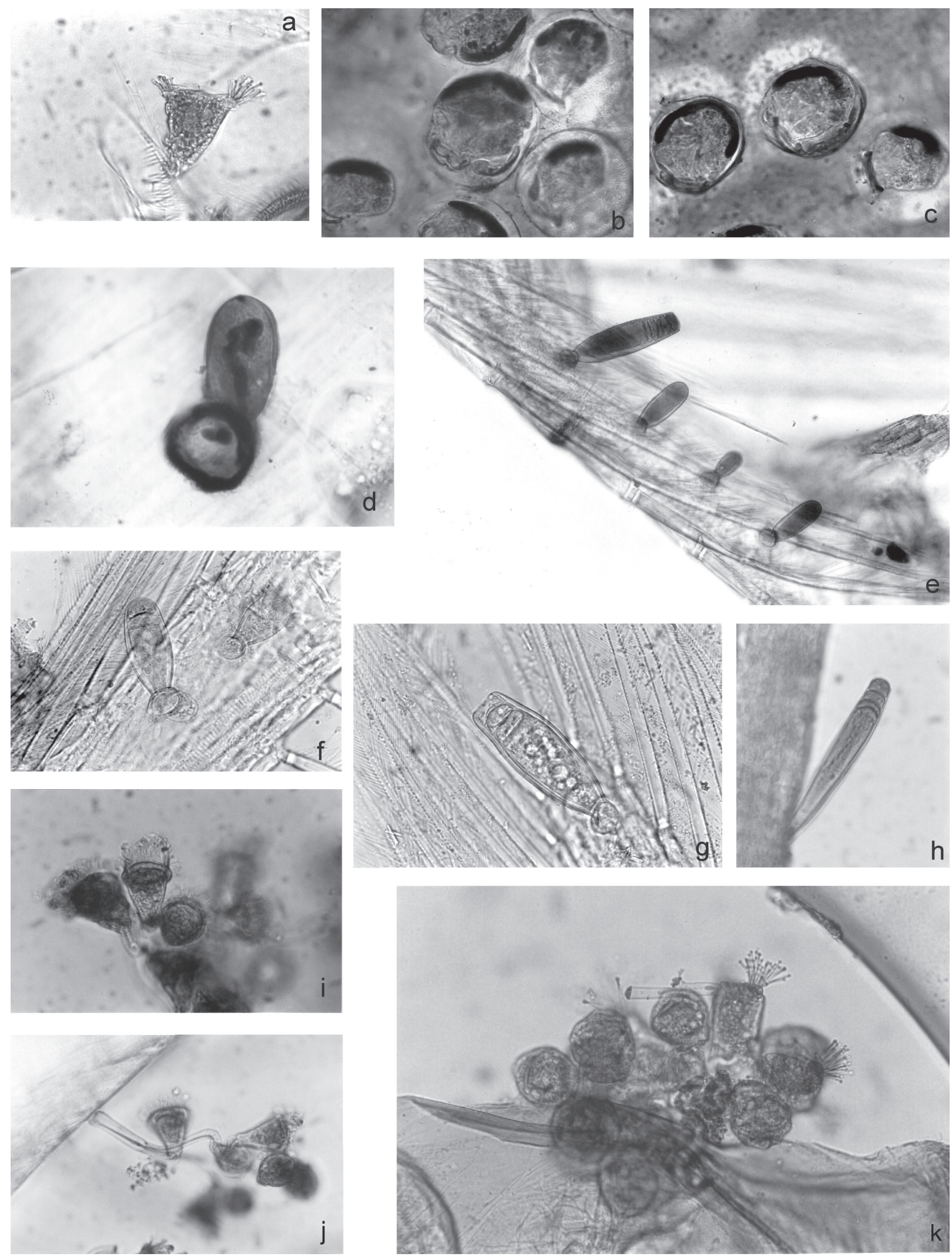
phylum Ciliophora Doflein, 1901

class Oligohymenophorea De Puytorac et al., 1974

subclass Peritrichia Stein, 1859

order Sessilida Kahl, 1933

family Lagenophryidae Bütschli, 1889

genus Lagenophrys Stein, 1851

Lagenophrys eupagurus Kellicot, 1893

(Figs. 4b, 5b, c ).

One diagnostic feature is the lips of the lorica aperture, both of which are thickened at the edge and divided into two parts by a deep cleft approximately in the middle. The point at which the anterior lip is divided is slightly off from the point at which the posterior lip is divided. The other diagnostic feature is the crescentshaped macronucleus, which is unusual for the genus. This ciliate is common symbiont of shrimp, although it also occurs on other decapods. The host type is the hermit crab Pagurus longicarpus Say, 1817, and it was found also on Upogebia affinis Say, 1818 (Clamp, pers.comm.) The lorica is hemispheroidal, subcircular or suboval in dorsal view. The anterior margin of lorica is nearly straight. The lorica is usually tapering slightly posteriad. The lorica rim is usually heavily thickened, occasionally only slightly to moderately thickened. The lips of lorica aperture are short, located distance equal to $1 / 5-1 / 6$ of length off lorica behind the anterior margin of lorica. Both lips are moderately arched. A trochal band of kinetosomes broken on right side ends of break is separated by a wide gap. Three peniculi exist. The macronucleus is cylindroid, elongate, curved, with an end thicker than the rest. The micronucleus is ovoid, usually near the center of macronucleus (Clamp, 1989).

phylum Ciliophora Doflein, 1901

order Apostomatida Chatton and Lwoff, 1928

genus Conidophrys Chatton and Lwoff, 1934

Conidophrys pitelkae Bradbury, 1975

(Figs. 4c, d, 5d-h).

Trophonts of 14-73 $\mu \mathrm{m}$ long, 7-18 $\mu \mathrm{m}$ wide (MayénEstrada and Aladro-Lubel, 1994). 95- $97 \mu \mathrm{m}$ long, 14-

Fig. 5. Epibiont species: a, Acineta tuberosa; b and c, Lagenophrys eupagurus; d-h, Conidophrys pitelkae with trophont (d), several individuals, trophonts and trophotomonts (e), and different developmental stages of trophotomonts (f-h); i-k, several colonies of Zoothamnium duplicatum.
18 wide (Bradbury and Tyson, 1982, from micrographs). These are ciliates with a life cycle dimorphic and related to the moult cycle of the basibiont crustacean. There is a trophont, long, cylindrical, tapering slightly at the proximal end, covered by a cyst wall. The cytostome contacted to the surface of the basibiont, the ciliate feeding on the cuticle of the basibiont (Bradbury and Tyson, 1982). The trophont becomes tropho-tomont when reproduced by tomitogenesis forming inside ciliated tomites. The tomites were finally released and may infest basibionts. When the tomite is attached to the host it becomes trophont. The tomont is 91-94 $\mu \mathrm{m}$ long, and 14-25 $\mu \mathrm{m}$ wide (MayénEstrada and Aladro-Lubel, 1994), 172-350 $\mu \mathrm{m}$ long, 25-44 $\mu \mathrm{m}$ wide (Bradbury and Tyson, 1982, from micrographs). It has been found as epibiont on Crangon crangon (Linnaeus, 1758) by Bradbury (1975) and (formerly) Penaeus setiferus (Linnaeus, 1767) by Mayén-Estrada and Aladro-Lubel, 1994.

phylum Ciliophora Doflein, 1901

class Oligohymenophorea De Puytorac et al., 1974

subclass Peritrichia Stein, 1859

order Sessilida Kahl, 1933

family Zoothamniidae Sommer, 1951

genus Zoothamnium Bory de St. Vincent, 1826

Zoothamnium duplicatum Kahl, 1933

(Figs. 4e, 5i-k).

These are colonial marine peritrichs, with the stalk dichotomously branched. The zooids are bell-shaped (60-82 $\mu \mathrm{m}$ long, 36-43 $\mu \mathrm{m}$ wide), with double-layered oral border. The macronucleus is C-shaped, transversely oriented. There is a single vacuole apically located. The outer two kineties of peniculus 3 are well separated from the inner one, with the middle kinety conspicuously shorter than others (Ji et al., 2006). It has not previously been described as epibiont.

\section{Distribution of epibionts}

The crustacean species showing the highest density of epibionts was Acetes indicus, with a maximum of 3,598 epibionts per basibiont, mainly due to the ciliate Lagenophrys. However, the basibiont with the highest mean density was Acetes sibogae (1,110 epibionts per crustacean). The basibionts from the open sea area (OS) (Acetes japonicus and Mesopodopsis orientalis caught on the sandy beach of Penang) showed the lowest densities of epibionts. Among the epibiont species 
Table 1. Length and width $(\mathrm{mm})$ of the basibiont species $(\mathrm{N}=20)$ and observed number of epibionts.

\begin{tabular}{|c|c|c|c|c|c|c|}
\hline \multirow{2}{*}{ Basibiont } & \multicolumn{2}{|l|}{ Length } & \multicolumn{2}{|l|}{ Width } & \multicolumn{2}{|c|}{ Epibionts per basibiont } \\
\hline & Mean \pm SD & Range & Mean \pm SD & Range & Mean \pm SD & Range \\
\hline Acetes indicus & $15.25 \pm 5.3$ & $(14.2-17)$ & $2.25 \pm 3.2$ & $(2-2.5)$ & $760.0 \pm 23.0$ & $(12-3593)$ \\
\hline A. japonicus & $12.10 \pm 2.3$ & $(9.5-20)$ & $2.30 \pm 0.1$ & $(1.5-7.5)$ & $83.6 \pm 3.1$ & $(1-607)$ \\
\hline A. japonicus OS & $9.93 \pm 3.1$ & $(8.5-11)$ & $1.64 \pm 0.8$ & $(1.5-2)$ & $9.60 \pm 4.3$ & $(0-36)$ \\
\hline A. sibogae & $21.83 \pm 4.3$ & $(15.5-21)$ & $3.25 \pm 1.1$ & $(3-3.5)$ & $1110.3 \pm 23.4$ & $(501-1588)$ \\
\hline Fenneropennaeus merguiensis & $12.17 \pm 3.2$ & $(9-16)$ & $2.35 \pm 0.7$ & $(1.5-3)$ & $72.1 \pm 5.2$ & $(0-271)$ \\
\hline Mesopodopsis orientalis M & $8.67 \pm 2.2$ & $(7-11)$ & $1.72 \pm 0.3$ & $(1-2)$ & $13.5 \pm 4.1$ & $(0-83)$ \\
\hline M. orientalis OS & $6.18 \pm 2.1$ & $(3-9)$ & $1.31 \pm 0.3$ & $(0.5-2)$ & $0.02 \pm 0.1$ & $(0-1)$ \\
\hline M.orientalis $\mathrm{T}$ & $7.17 \pm 2.2$ & $(4.5-10)$ & $1.32 \pm 0.3$ & $(0.5-2)$ & $81.8 \pm 8.2$ & $(0-277)$ \\
\hline M.orientalis B & $9.33 \pm 3.2$ & $(8-11)$ & $1.66 \pm 0.2$ & $(1.5-2)$ & $19.0 \pm 2.3$ & $(15-25)$ \\
\hline M. orientalis $\mathrm{C}$ & $3.33 \pm 0.8$ & $(3-4)$ & $1.00 \pm 0.0$ & & $12.8 \pm 5.2$ & $(1-20)$ \\
\hline
\end{tabular}

Table 2. Morphometrics (in mm) $(\mathrm{N}=60)$ of the epibionts (after fixation) observed on Mesopodopsis orientalis, Acetes spp. and Fenneropenaeus spp.

\begin{tabular}{|c|c|c|c|c|c|c|}
\hline \multirow{2}{*}{$\begin{array}{l}\text { Basibiont species } \\
\text { Epibiont species }\end{array}$} & \multicolumn{2}{|c|}{ Mesopodopsis orientalis } & \multicolumn{2}{|l|}{ Acetes spp. } & \multicolumn{2}{|c|}{ Fenneropenaeus spp. } \\
\hline & Mean \pm SD & Range & Mean \pm SD & Range & Mean \pm SD & Range \\
\hline \multicolumn{7}{|l|}{ Acineta tuberosa } \\
\hline Body length & $21.75 \pm 8.26$ & $(10.30-28.10)$ & $36.30 \pm 16.23$ & $(13.44-63.36)$ & $38.11 \pm 13.07$ & $(19.20-61.44)$ \\
\hline Body width & $13.75 \pm 5.12$ & $(9.34-21.06)$ & $30.19 \pm 5.57$ & $(19.20-40.32)$ & $33.69 \pm 5.44$ & $(21.12-42.24)$ \\
\hline Macronucleus length & $6.38 \pm 2.49$ & $(4.00-9.15)$ & $9.60 \pm 1.71$ & $(7.68-11.52)$ & $13.08 \pm 6.24$ & $(5.76-24.96)$ \\
\hline Macronucleus width & $3.50 \pm 0.57$ & $(3.46-4.12)$ & $9.28 \pm 1.88$ & $(7.65-11.51)$ & $8.04 \pm 1.88$ & $(3.84-13.44)$ \\
\hline \multicolumn{7}{|l|}{ Zoothamnium duplicatum } \\
\hline Body length & $16.71 \pm 1.88$ & $(13.70-19.40)$ & $28.18 \pm 4.42$ & $(19.20-36.48)$ & $28.12 \pm 4.32$ & $(21.11-40.32)$ \\
\hline Body width & $12.28 \pm 0.48$ & $(12.20-13.20)$ & $23.57 \pm 2.44$ & $(21.12-28.80)$ & $25.44 \pm 5.42$ & $(19.30-35.19)$ \\
\hline Stalk length & $30.40 \pm 7.95$ & $(20.40-40.37)$ & $164.16 \pm 37.64$ & (119.04-211.20) & $237.80 \pm 78.14$ & $(96.00-316.80)$ \\
\hline Stalk width & $4.30 \pm 0.67$ & $(3.50-5.20)$ & $6.72 \pm 1.10$ & $(5.76-7.68)$ & $6.85 \pm 2.57$ & $(3.84-9.60)$ \\
\hline \multicolumn{7}{|l|}{ Conidophrys pitelkae } \\
\hline Body length & $12.25 \pm 0.95$ & $(11.06-13.00)$ & $100.87 \pm 32.40$ & $(38.40-142.08)$ & $93.67 \pm 40.45$ & $(24.96-93.00)$ \\
\hline Body width & $5.75 \pm 0.50$ & $(5.40-6.67)$ & $18.46 \pm 5.73$ & $(11.52-28.80)$ & $13.64 \pm 5.12$ & $(5.76-19.20)$ \\
\hline \multicolumn{7}{|l|}{ Lagenophrys eupagurus } \\
\hline Body length & $21.50 \pm 5.89$ & $(12.27-28.50)$ & $38.11 \pm 7.35$ & $(19.20-49.92)$ & $45.36 \pm 9.19$ & $(30.72-59.52)$ \\
\hline Body width & $14.16 \pm 6.55$ & $(6.20-21.70)$ & $36.28 \pm 7.72$ & $(17.20-47.63)$ & $37.08 \pm 12.43$ & $(13.44-63.36)$ \\
\hline
\end{tabular}

Table 3. Epibionts observed along the longitudinal axis of the basibiont over five groups of anatomical units.

\begin{tabular}{|c|c|c|c|c|c|}
\hline \multirow[b]{2}{*}{ Basibiont species, locality } & \multicolumn{5}{|l|}{ Anatomical units } \\
\hline & $\begin{array}{l}\text { Rostrum, eyes, } \\
\text { antennae, } \\
\text { antennulae }\end{array}$ & $\begin{array}{l}\text { Maxillae, } \\
\text { maxillipeds }\end{array}$ & Pereiopods & Pleopods & $\begin{array}{l}\text { Uropods, } \\
\text { telson }\end{array}$ \\
\hline Acetes indicus & 1075 & 150 & 496 & 390 & 142 \\
\hline Acetes japonicus & 388 & 43 & 5 & 311 & 89 \\
\hline Acetes japonicus, OS & 15 & 0 & 0 & 78 & 3 \\
\hline Acetes sibogae & 1228 & 164 & 384 & 1039 & 498 \\
\hline Fenneropenaeus merquiensis & 1112 & 19 & 16 & 200 & 95 \\
\hline Mesopodopsis orientalis & 29 & 0 & 36 & 169 & 28 \\
\hline Mesopodopsis orientalis, $\mathrm{T}$ & 323 & 0 & 564 & 653 & 196 \\
\hline Mesopodopsis orientalis, B & 1 & 0 & 13 & 3 & 40 \\
\hline Mesopodopsis orientalis, C & 0 & 0 & 1 & 9 & 28 \\
\hline Mesopodopsis orientalis, OS & 0 & 0 & 1 & 0 & 0 \\
\hline
\end{tabular}




\begin{tabular}{|c|c|c|c|c|c|c|c|}
\hline \multicolumn{2}{|l|}{ Acineta sp. } & \multicolumn{2}{|c|}{ Lagenophrys sp. } & \multicolumn{2}{|c|}{ Conidophrys sp. } & \multicolumn{2}{|c|}{ Zoothamnium sp. } \\
\hline Mean \pm SD & Range & Mean \pm SD & Range & Mean \pm SD & Range & Mean \pm SD & Range \\
\hline $1.00 \pm 0.3$ & $(0-4)$ & $535.3 \pm 22.7$ & $(0-1685)$ & $4.00 \pm 0.7$ & $(0-8)$ & $30.3 \pm 14.0$ & $(0-106)$ \\
\hline $0.10 \pm 0.5$ & $(0-1)$ & $69.0 \pm 4.2$ & $(0-607)$ & $10.5 \pm 1.3$ & $(0-36)$ & $4.00 \pm 2.2$ & $(0-17)$ \\
\hline $0.30 \pm 0.2$ & $(0-3)$ & & & $9.30 \pm 3.2$ & $(0-36)$ & & \\
\hline $202.7 \pm 12.2$ & $(0-577)$ & $650.3 \pm 12.3$ & $(451-1028)$ & $36.7 \pm 4.6$ & $(8-79)$ & $211.3 \pm 13.4$ & $(42-432)$ \\
\hline $15.2 \pm 3.4$ & $(0-72)$ & $4.75 \pm 1.2$ & $(0-21)$ & $12.2 \pm 4.6$ & $(0-67)$ & $39.9 \pm 5.2$ & $(0-164)$ \\
\hline $10.9 \pm 2.2$ & $(0-82)$ & $0.30 \pm 0.1$ & $(0-6)$ & $0.23 \pm 0.1$ & $(0-3)$ & $1.38 \pm 0.7$ & $(0-26)$ \\
\hline $0.02 \pm 0.1$ & $(0-1)$ & & & & & & \\
\hline $72.8 \pm 6.1$ & $(0-252)$ & & & & & $3.60 \pm 1.1$ & $(0-31)$ \\
\hline $2.33 \pm 0.7$ & $(1-4)$ & & & $2.33 \pm 0.3$ & $(0-6)$ & $14.3 \pm 4.1$ & $(9-21)$ \\
\hline $12.7 \pm 4.2$ & $(1-20)$ & & & & & & \\
\hline
\end{tabular}

presented, Acineta appeared on all basibiont species. Among the basibionts Mesopodopsis orientalis OS showed the lowest proportion of epibiont species (Table 1).

The general biometrical characteristics of the epibiont species (Table 2) were compared between the three genera of basibionts. Acineta, Zoothamnium and Conidophrys did not show significant differences, but $\mathrm{La}$ genophrys showed a statistically significant difference $(F=14.92 ; p<0.05$, df 3$)$. The body size of individual epibionts was largest in Fenneropennaeus and smallest in Mesopodopsis and in Acetes they showed intermediate values. This epibiont was also present in high densities in Acetes, while in Fenneropenaeus and Mesopodopsis, it was found in lower abundance. The mean densities of epibionts on the different anatomical units of the basibionts were calculated considering the longitudinal axis of the crustacean. There were species showing a high level of colonization on the anterior areas of the body, such as A. indicus, A. japonicus, $A$. sibogae and F.merguiensis, while A. japonicus $\mathrm{OS}$ and various populations of $M$. orientalis tended to be heavier colonized towards the posterior part of the body. Multiple comparison analysis indicated a significant difference between the species $(F=9.53 ; p<0.05$, df $9)$. There were significant differences between $A$. japonicus and A. japonicus $O S$, and also between $M$. orientalis and M. orientalis $O S$.

The anatomical units were subdivided into five groups through the anterioposterior axis of the basibiont (1, rostrum, eyes, antennulae, antennae; 2 , maxillae, maxillipeds; 3 , pereiopods; 4 , pleopods, 5 , uropods and telson). Group 1 dominated in A. indicus and $F$. merguiensis, where it accounted for $47.7 \%$ and $77.1 \%$ of the epibionts respectively. In contrast, $A$. japonicus and A. sibogae presented similar higher proportions on pleopods (37.2 and 31.4\%) and the most anterior part of the body (rostrum, eyes, antennulae and antennae) (46.4 and 37.1\%). Pleopods were the most colonized units on A. japonicus $O S, M$. orientalis and M. orientalis $T$ (Table 3). Multiple comparison analysis on these data showed a significant difference between the species $(F=3.92 ; p<0.05$, df 6$)$.

In each basibiont species, epibiont species generally presented a different distribution. This was corroborated by multiple comparison analysis. In $A$. indicus, A. japonicus, A. sibogae, M. orientalis $\mathrm{M}, M$. orientalis $\mathrm{T}$, and A. japonicus OS there was a significant difference between the distributions of epibiont species. However, in the case of F. merguiensis and $M$. orientalis $\mathrm{B}$, a statistically significant difference was not found.

On the other hand, taking into account the mean densities of epibionts on each anatomical unit of the Mesopodopsis orientalis, multiple comparison analysis showed a significant difference between the epibiosis in the diverse geographical areas sampled $(F=48.43 ; p$ $<0.05, \mathrm{df} 4)$. As in the analysis of data with respect to the longitudinal axis of the basibiont, M. orientalis and M. orientalis OS, as well as A. japonicus and A.japonicus $O S$, presented a statistically significant difference $(t=4.91$ and $t=3.39$ respectively; $p<0.05)$.

A principal component analysis was performed using the mean densities of epibionts in each anatomical unit of the different basibiont species. The two first principal components showed three clusters: (1) a group including all species of Mesopodopsis except $M$. orientalis OS; (2) a group consisting of the species of Acetes and F. merguiensis and (3) M. orientalis OS (Figure 6).

This analysis indicated the peculiar epibiosis in Acetes and Mesopodopsis, and also the difference with 
Fig. 6. Principal component classification of basibiont species, based upon epibiont density. Clusters are (1) a group including all species of Mesopodopsis except $M$. orientalis OS; (2) a group consisting of the species of Acetes and $F$. merguiensis and (3) M. orientalis OS.
Fig. 7. Dendrogram of the hierarchical conglomerate analysis performed using the mean density of epibionts on the anatomical units of the basibiont species (Lant, Rant, left and right antennae; Lantl, Rantl, left and right antennulae; Leye, Reye, left and right eyes; Lmax, Rmax, left and right maxillae; Lmxp, Rmxp, left and right maxillipeds; L1-5per, left 1-5 pereipods; R1-5per, right 1-5 pereiopods; L1-5ple, left 1-5 pleopods; R1-5ple, right 1-5 pleopods. Luro, Ruro, left and right uropods; tel, telson).

Fig. 8. Mean density of epibionts observed over the anterioposterior axis of the basibiont genera Acetes (diamond symbols), Fenneropenaeus (square symbols) and Mesopodopsis (round symbols). (1, rostrum; 2 , antennulae; 3 , antennae; 4, eyes; 5, maxillae, 6 , maxillipeds; 7, first pereiopods; 8 , second pereipods; 9 , third pereipods; 10 , fourth pereipods; 11 , fifth pereiopods; 12 , first pleopods; 13 , second pleopods; 14 , third pleopods; 15 , fourth pleopods; 16, fifth pleopods; 17 , uropods; 18 , telson).
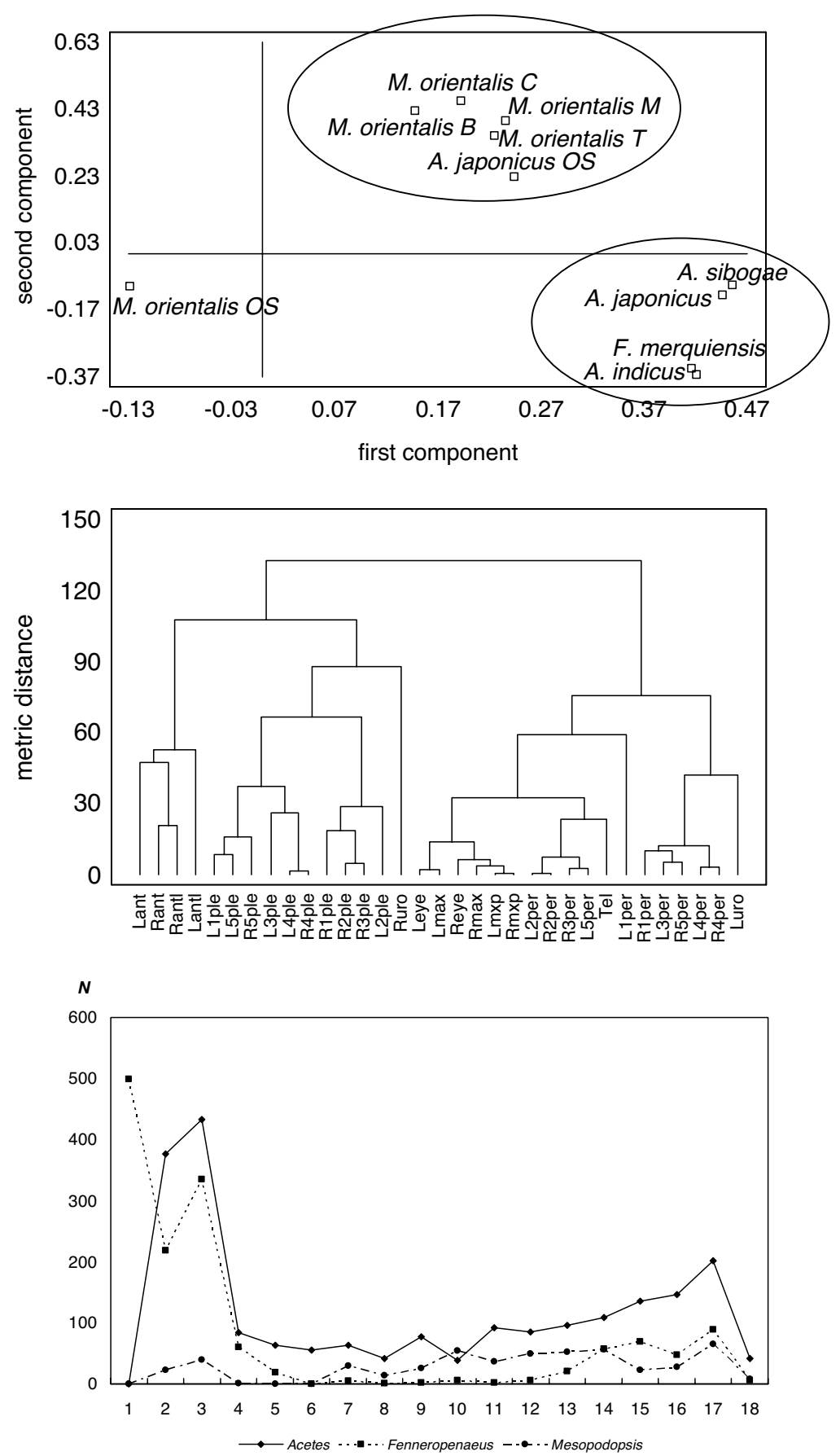

regard to open sea species. This result coincided with the result obtained in hierarchical conglomerate analysis, in which also three similar clusters appeared in the dendrogram (Fig. 7). In this analysis, the different anatomical units of the basibionts were also considered. The dendrogram indicated that the units were grouped into four clusters: (1) the first cluster represented $12.1 \%$ of the units with the highest density of epibionts (mean 91.33 epibionts per anatomical unit), and included the antennae and antennulae; (2) the second cluster comprised $33.3 \%$ of the anatomical units (pleopods and right uropod) with high density of epibionts (mean 39.05 epibionts per unit); (3) the third cluster included units (36.4\% of the total units) with the lowest density 
of epibionts (1373 epibionts per unit), eyes, maxillae, maxillipeds, left first pereiopod, second pereiopods, right third pereiopod, left fifth pereiopod and telson and (4) the fourth cluster represented $18.2 \%$ of the units, with a moderate density of epibionts (mean 22.27 epibionts per unit), and included the right first, left third, right fifth and fourth pereiopods, and the left uropod.

A multiple regression analysis was made involving total mean density of epibionts in the different areas sampled and temperature, salinity, mean length and mean width of the basibionts. At the $90 \%$ confidence level there is a statistically significant relationship between variables, length and width being the variables with lower p-values and high significance. In contrast, temperature was the variable with the lowest significance. Correlation analysis showed a significant relationship between the total mean number of epibionts and the length and width of the basibionts $(0.87$ and 0.76 respectively, $p<0.05$ ). MANOVA performed with total mean densities of epibionts showed a significant relationship with the different basibiont species and with the length and width of the basibionts The analysis of variance indicated that length was the variable most strongly contributing to the variance of the total number of epibionts.

In order to compare the different basibiont genera, overall mean values of density of epibionts on the different anatomical units were calculated for Fenneropenaeus, Acetes and Mesopodopsis from the mangrove areas. The multiple comparison analysis indicated that the three genera showed significant differences with respect to the distribution of epibionts $(F=5.13 ; p<0.05)$. The highest difference was observed between Mesopodopsis and Acetes ( $t=4.95 ; p<0.05$, df 2$)$. In general, Acetes specimens tend to have the anterior appendages (antennulae and antennae) heavily colonized and also, secondarily, on the posterior pleopods and uropods. In contrast, Mesopodopsis specimens showed the highest colonization on the posterior pereiopods, pleopods and uropods, while anterior areas of the body had lower densities of epibionts. Fenneropenaeus specimens exhibited a clear colonization on the most anterior areas (rostrum, antennulae and antennae) (Figure 8).

\section{Discussion}

The crustacean basibionts of this study are rather common and familiar to carcinologists because of their commercial importance, although their etiology in the tropical mangroves is poorly studied. The epibiont species found constituted the first record of their presence on the crustacean species of this study. These epibionts have previously been found on other crustacean species (Morado and Small, 1995). The genus Acineta has been described on gammarids, decapods, cladocerans, ostracods, copepods and isopods, with a higher diversity of species on gammarid amphipods (Fernandez-Leborans and Tato-Porto, 2000a; Morado and Small, 1995). Species in the genus Zoothamnium are also very common epibionts and have been recorded previously on gammarids, isopods, decapods and copepods, also with a higher diversity on gammarid amphipods. This is probably due to the fact that epibiosis on freshwater gammarids have been more profusely studied (Fernandez-Leborans and Tato-Porto, 2000b; Morado and Small, 1995). Although these ciliates may be found attached to other substrata, Lagenophrys peritrichs are typically found as epibiont on crustaceans, having been recorded on decapods, gammarids, isopods, cladocerans, ostracods and copepods, with a higher diversity on decapods and gammarid amphipods (Fernandez-Leborans and Tato-Porto, 2000b; Morado and Small, 1995). The pilisuctorian genus $\mathrm{Co}$ nidophrys has been observed only on crustaceans. $\mathrm{Co}$ nidophrys pilisuctor has been observed on marine amphipods and isopods from the coasts regions in the northern hemisphere (Chatton and Lwoff, 1934, 1936; Mohr and Leveque, 1948; Fenchel, 1965; Jones and Khan, 1970; Boshko and Dovgal, 2000). Subsequently, Mayén-Estrada and Aladro-Lubel (2004) have described this species on the freshwater amphipod Hyalella azteca from Mexico. Conidophrys pitelkae was found on the sand shrimp Crangon crangon from the Atlantic coast of France (Bradbury, 1975), and later on several decapod species from the Atlantic coast of Mexico (Mayén-Estrada and Aladro-Lubel, 1994).

The suctorian genus Acineta is a predator that feeds principally on other ciliates, although it may also eat algae. Zoothamnium spp are peritrich ciliates that consume particulate organic material suspended in the water, especially bacteria. Some species can also feed on algae. The peritrich genus Lagenophrys feed on detritus, diatoms and dinoflagellate from the surface of the bottom substratum, and when the basibiont moves the sediment re-suspends the nutrient due to its feeding activity. This ciliate can be found in large densities on the basibiont. As its body is conspicuously flattened, the individuals may completely cover the surface of the anatomical units colonized. The pilisuctorian genus Conidophrys can be considered as a parasite organism, since the individuals possesses a feeding apparatus or 
citostome that can connect to the exoskeleton of the basibiont, liquefy it by means of an enzymatic action, and incorporate the fluids from the cuticle into food vacuoles. The ingestion structure is composed of a microtubular and fibrillar subcellular bag-shaped device similar to the rosette of other apostomatids (Bradbury and Tyson, 1982).

Lagenophrys was abundant in Acetes, but not in Mesopodopsis and Fenneropenaeus. There are two possible reasons for this: Lagenophrys prefers large-sized, more powerful swimming basibionts; or this epibiont prefers the sublittoral zone rather than the littoral zone for its mode of feeding as it is a detritus feeder.

There is a significant correlation in epibiosis in general where larger-sized basibionts carry a large number of epibionts. Mesopodopsis reach 7-8 mm BL at most. Adult Acetes reach $30-40 \mathrm{~mm}$ BL or slightly more. Juveniles of Fenneropenaeus examined in this study were intermediated between them (ca $20 \mathrm{~mm}$ ). Usually, smaller crustaceans (or juveniles) are assumed to have a shorter inter-moult period than larger and adult crustaceans; this may affect the formation of epibiont assemblages.

The epibiosis in each crustacean species and in each sampling locality showed a particular pattern which was revealed by the statistical analysis. Taking into consideration the same basibiont species, e.g., Mesopodopsis, the pattern of epibiosis was statistically different among the different sampling sites, and this could be due to the different ecological conditions. In general, the colonization was predominantly observed on the anterior part of the body in Acetes and Fenneropenaeus, and it tends to be more abundant on the mid and posterior areas in Mesopodopsis. However, the different epibiont species varied their location according to the structure of the community and the basibiont species. In Mesopodopsis, when all the epibiont species were present, Acineta and Zoothamnium were located mainly on the middle and posterior areas of the body, whereas Conidophrys and Lagenophrys were attached anteriorly. In contrast, in Acetes, where Lagenophrys was noticeably abundant, this ciliate species and Acineta colonized mainly on the anterior areas, while Zoothamnium and Conidophrys were found posteriorly. Fenneropenaeus clearly showed a higher colonization on the anterior areas of the body, possibly because in this zone the appendages provide wide areas for the settlement of the epibionts, together with the presence of nutrients from the feeding activity by the buccal appendages of the crustacean basibiont.

The distribution of the epibiont species is related to specific basibiont species, and the pattern of colonization of the epibiont community. In this study, their distribution showed a trend similar to that observed in other areas, e.g., the epibiosis on Caridina lanceolata from the Malili lakes of Sulawesi (Fernandez-Leborans et al., 2006): the epibiont species were located following a particular pattern, which the results show: the species tended to be correlated to the different lakes. Independently of the present species and in all cases, each species was established fitting the same general way of distribution. In each basibiont species, each epibiont species followed a distribution pattern related to that of other epibiont species present. The epibionts tend to occupy the sites available fitting the whole surface with adequate environment for colonization (nutrient input, protection against predators, abrasion or other antifouling mechanisms, hydrodynamic effects, etc.). When an epibiont would have a relation with a different basibiont species, the pattern of colonization may be modified. The basibiont represents a dynamic environment in which the epibiont community species acquire a colonization pattern. The short generation time, the dispersion, and the adaptations to the epibiotic life, confer to ciliate protozoans numerous advantages in colonization. An indication of this fact is the numerous protozoan communities described as epibionts in many crustacean species (Morado and Small, 1995; FernandezLeborans and Tato-Porto, 2000a, b).

The changes in the community structure of protozoans may significantly affect other components of the aquatic food web, and may thus influence the distribution and abundance of both lower and higher organisms (Beaver and Crisman, 1989; Carrick and Fahnenstiel, 1992). Ciliates have an important ecological significance in free environments, especially in benthic areas, where they show high growth rates and important trophic diversity (Patterson et al. 1989; Fenchel, 1990; Fernandez-Leborans and Fernandez-Fernandez, 2002). Although in a small scale, these conditions could be transferred to an epibiotic community, which could reflect the biodiversity in the environment (Fernandez-Leborans and Gabilondo, 2006).

A slightly harsher condition in the littoral zone of the open sandy beach could attribute to a lower incidence of epibionts as compared with the estuarine counterparts which inhabit a calm environment. Another possibility is that high productivity in the mangrove estuary could contribute to a higher incidence of epibionts. Chong et al. (2003) suggested that the zooplankton biomass in the Matang mangrove swamp is noticeably higher than that in its offshore waters. The 
biomass of littoral hyperbenthos is also appreciably higher in the mangrove estuaries than in the coastal area without mangrove (Hanamura et al., unpublished data). This may reflect higher primary productivity in the mangrove swamp (see also Tanaka and Choo, 2000), and it would also provide rich foods for epibiont ciliates.

Otherwise, the marked difference in the incidence of epibiosis gives an indication of ecological separation between the estuarine and coastal populations. They usually stay in their own habitats for a considerable time and consequently the interactions between the two populations do not occur frequently. In the studied mangrove estuaries, the water temperature was rather stable throughout the year. In contrast, the salinity showed a wide range of variations according to the rainfalls. The hyperbenthic crustaceans in the mangrove estuary evidently showed considerably wide euryhalinity (Hanamura et al., in press a, b): hence, the crustacean epibionts found in this study may also have a broad range of salinity tolerance corresponding with their basibionts.

Large-sized basibionts provide a wider substratum to be attached for epibionts. In this respect, the appendages of Acetes are markedly wider than those of Mesopodopsis (Fig. 3). In addition, the inter-moult period of basibionts may quantitatively and qualitatively contribute to the epibiont assemblage. For example, juveniles of Fenneropenaeus may have a shorter intermoult duration than that of adult Acetes. Mesopodopsis are also assumed to have comparatively shorter instar stages when compared with Acetes. The incidence of epibiosis is much lower in the coastal area. Environmental conditions in the mangrove swamp is assumed to have a higher primary productivity than in off shore areas. As mentioned before, the physical condition also differs between the two, but the former factor is believed to be more important. Taking into account the special characteristics of the epibiotic association, in many cases it is not easy to find colonized basibiont individuals. This is the reason for the relatively low number of infested specimens analyzed in each species and locality. In addition, the time required for the detailed observation of the anatomical units of the basibiont and the count of the epibionts of diverse species on these units must be taken into account, since different basibiont species and sites were considered. The principal aim of the work was to obtain a general view of the epibiosis on mangrove dominant crustacean species in Malaysia and their special characteristics on basibiont species and sites.

\section{Acknowledgements}

We thank Dr. Yoshimi Fujioka, who made the sample obtained in Thailand available for this study.

\section{References}

Abelló P, Villanueva R, Gili JM. 1990. Epibiosis in deep-sea crab populations as indicator of biological and behavioural characteristics of the host. Journal of the Marine Biological Association of the United Kingdom 70: 687-695.

Beaver JR, Crisman TL. 1989. The role of ciliated protozoa in pelagic freshwater ecosystems. Microbial Ecology 17: 111136.

Becker K, Wahl M. 1996. Behaviour patterns as natural antifouling mechanisms of tropical marine crabs. Journal of experimental marine Biology and Ecology 203: 245-258.

Boshko EG, Dovgal IV. 2000. The first record of pilisuctorid ciliates (Ciliophora, Pilisuctorida) in the Black Sea. Vestnik Zoologii 34: 112.

Bradbury PC. 1975. Conidophrys pitelkae, a new species of pilisuctorian from cuticular hairs of Crangon crangon (Linnaeus), Acta Protozoologica 14: 161-170.

Bradbury PC, Tyson GE. 1982. The fine structure of Conidophrys pitelkae Bradbury related to its life cycle and taxonomic position in the Apostomatida. Journal of Protozoology 29: 184-194.

Brusca RC, Brusca GJ. 1990. Invertebrates. Sunderland, Mass.: Sinauer Associates Inc.

Bush, AO, Fernández JC, Esch GW, Seed JR. 2001. Parasitism: The Diversity and Ecology of Animal Parasites. Cambridge, UK: Cambridge University Press.

Carman KR, Dobbs FC. 1997. Epibiotic microorganisms on copepods and other marine crustaceans. Microscopical Research and Techniques 37: 116-135.

Carpenter KE, Niem VH. 1988. FAO species identification guide for fishery purpose of the Western Central Pacific. Vol. 2. Cephalopods, crustaceans, holothuridans and sharks. Rome: FAO, 687-1396.

Carrick HJ, Fahnenstiel GL. 1992. Growth and production of planktonic protozoa in Lake Michigan. In situ versus in vitro comparison and importance to food web dynamics. Limnology and Oceanography 37: 1221-1235.

Chatton E, Lwoff A. 1934. Sur un infusoire parasite des poils sécréteurs des Crustacés Edriophtalmes et la famille nouvelle des Pilisuctoridae. Comptes Rendus Académie des Sciences Paris 199: 696-699.

Chatton E, Lwoff A. 1936. Les Pilisuctoridae Ch. et Lw. Ciliés parasites des poils sécréteurs des Crustacés Edriophtalmes. Polarité, orientation et desmodexie chez les infusoires. Bulletin Biologie France Belgique 70: 86-144.

Chew L-L, Ooi A-L, Chong V-C, Ogawa Y. 2006. The diet of five major fish species in Matang mangrove estuaries, Peninsular Malaysia. JIRCAS Working Report 44: 7-13.

Chong, VC, Ooi AL, Chew LL, Ogawa Y. 2003. Mangrove zooplankton of Matang mangrove estuaries: preliminary assessment of spatio-temporal abundance in relation to environmental parameters. JIRCAS Working Report 35: 21-43. 
Clamp JC. 1989. Redescription of Lagenophrys eupagurus Kellicot (Ciliophora, Peritrichida, Lagenophryidae) and a comparison of it with three similar species. Journal of Protozoology 36: 596-607.

Connell JH, Keough MJ. 1985. Disturbance and patch dynamics of subtidal marine animals on hard substrata. In: STA Picket, PS White eds. The ecology of natural disturbance and patch dynamics. London: Academic Press.

Corliss JO. 1979. The Ciliated Protozoa, Characterization, Classification and Guide to the Literature. $2^{\text {nd }}$ edition. New York: Pergamon Press.

Curds CR. 1985. A revision of the Suctoria (Ciliophora, Kinetofragminophora). 1. Acineta and its morphological relatives. Bulletin British Museum (Natural History) Zoology 48: 75129.

Enderlein P, Wahl M. 2004. Dominance of blue mussels versus consumer.mediated enhancement of benthic diversity. Journal of Sea Research 51: 145-155.

Fenchel T. 1965. On the ciliated fauna associated with the marine species of the amphipod genus Gammarus J.G. Fabricius. Ophelia 2: 281-303.

Fenchel T. 1990. The role of protozoa in nature in terms of functional properties related to size. Zoological Science 7: 51-58.

Fernandez-Leborans G, Castro de Zaldumbide M. 1986. The morphology of Anophrys arenicola n. sp. (Ciliophora, Scuticociliatida). Journal of Natural History 20: 713-721.

Fernandez-Leborans G, Fernandez-Fernandez D. 2002. Protist functional groups in a sublittoral estuarine epibenthic area. Estuaries 25: 382-392.

Fernandez-Leborans G, Gabilondo R. 2006. Inter-annual variability of the epibiotic community on Pagurus bernhardus from Scotland. Estuarine and Coastal Shelf Science 66: 35-54.

Fernandez-Leborans G, Tato-Porto ML. 2000a. A review of the species of protozoan epibionts on crustaceans. I. Suctorian ciliates. Crustaceana 73: 1205-1237.

Fernandez-Leborans G, Tato-Porto ML. 2000b. A review of the species of protozoan epibionts on crustaceans. I. Peritrich ciliates. Crustaceana 73: 643-684.

Fernandez-Leborans G, Zitzler K, Gabilondo R. 2006. Epibiont protozoan communities on Caridina lanceolata (Crustacea, Decapoda) from the Malili lakes of Sulawesi (Indonesia). Zoologische Anzeiger 245: 167-191.

Gili JM, Abelló P, Villanueva R. 1993. Epibionts and intermoult duration in the crab Bathynectes piperitus. Marine Ecology Progress Series 98: 107-113.

Hanamura Y, Siow R, Chee P-E. Abundance and spatio-temporal distribution of Acetes shrimp (Crustacea, Decapoda, Sergestidae) in the Merbok and Matang Mangrove Estuaries, Peninsular Malaysia. Malaysian Fish Journal (in press a).

Hanamura Y, Siow R, Chee P-E. Abundance and spatio-temporal distribution of hyperbenthic crustaceans in the Merbok and Matang mangrove estuaries, Malaysia. JIRCAS Work Report (in press b).

Ji D, Song W, Al-Rasheid KAS, Sun P. 2006. Description of Zoothamnium foissneri $\mathrm{n}$. sp. and redescription of Z. duplicatum Kahl, 1933 and Z. mucedo Entz, 1884, three species of marine peritrichous ciliates. European Journal of Protistology 41: 45-56.

Jones MB, Khan MA. 1970. The occurrence of Conidophrys species (Protozoo, Ciliata) on members of the Jaera albifrons Leach group. Acta Protozoologica 8: 149-153.
Key J, Volpe W, Jeffries WB, Voris HK. 1997. Barnacle fouling of the blue crab Callinectes sapidus at Beaufort, North Carolina. Journal of Crustacean Biology 17: 424-439.

Key MM, Winston JE, Volpe JW, Jeffries WB, Voris HK. 1999. Bryozoan fouling of the blue crab Callinectes sapidus at Beaufort, North Carolina. Bulletin of marine Science 64: 513-533.

Kiso K, Mahyam MI. 2003. Distribution and feeding habits of juvenile and young John's snapper Lutjanus johnii in the Matang mangrove estuary, west coast of Peninsular Malaysia. Fisheries Science 69: 563-568.

Laudien J, Wahl M. 2004. Associational resistance of fouled blue mussels (Mytilus edulis) against starfish (Asterias rubens) predation: relative importance of structural and chemical properties of the epibionts. Helgoland Marine Research 58:162-167.

Lynn DH, Small EB. 2000. Phylum Ciliophora. In: JJ Lee, GF Leedale, P Bradbury, eds. An Illustrated Guide to the Protozoa, Kansas: Allen Press, 371-656.

Mayén-Estrada R, Aladro-Lubel MA. 1994. Primer registro de Conidophrys pitelkae (Ciliophora, Apostomatia, Pilisuctorida) en crustáceos decápodos de la laguna de Tamiahua, Veracruz. Anales Instituto Biologia Universidad Nacional Autónomica México Zool 65: 1-10.

Mayén-Estrada R, Aladro-Lubel MA. 2004. First record of $C o$ nidophrys pilisuctor (Ciliophora, Pilisuctorida) as ectosymbiont of Hyalella azteca from Mexico. Hydrobiologia 529: 19-26.

Mohr JL, Leveque JA. 1948. Occurrence of Conidophrys pilisuctor on Corophium acherusicum in Californian waters, Abstract. Journal of Parasitology 34: 253.

Morado JF, Small EG. 1995. Ciliate parasites and related diseases of Crustacea, a review. Reviews in Fisheries Science 3: 275-354.

Patterson DJ, Larsen J, Corliss JO. 1989. The ecology of heterotrophic flagellates and ciliates living in marine sediments. Progress Protistology 3: 185-277.

Ross DM. 1983. Symbiotic relations. In: DE Bliss, ed. The biology of Crustacea, vol. 7, 163- 212.

Small EB, Lynn DH. 1985. Phylum Ciliophora. In: JJ Lee, SH Hutner, EC Bovee, eds. An Illustrated Guide to the Protozoa, Kansas: Allen Press, 393-575.

Tanaka K, Choo P-S. 2000. Influence of nutrient outwelling from the mangrove swamp on the distribution of phytoplankton in the Matang Mangrove Estuary, Malaysia. Journal of Oceanography 56: 69-78.

Then A, Chong V-C, Moh H-H, Hanamura Y. 2006. Size frequency, abundance and feeding habits of young snappers (Lutjanus spp.) and groupers (Epinephelus spp.) in the Matang Mangrove Estuary, Malaysia. JIRCAS Work Report 44: 1-6.

Threlkeld ST, Chiavelli DA, Willey RL. 1993. The organization of zooplankton epibiont communities. Trends in Ecology and Evolution 8: 317-321.

Utz LR. 2003. Identification, life history, and ecology of peritrich ciliates as epibionts on calanoid copepods in the Chesapeake Bay. Ph.D. dissert. Univ. of Maryland.

Wahl M. 1989. Marine epibiosis. I. Fouling and antifouling. Some basic aspects. Marine Ecology Progress Series 58: 175-189.

Wahl M, Mark O. 1999. The facultative nature of epibiosis: experimental and observational evidence. Marine Ecology Progress Series 187: 59-66. 
Williams JD, McDermott JJ. 2004. Hermit crab biocoenoses: a worldwide review of the diversity and natural history of hermit crab associates. Journal of experimental marine Biology and Ecology 305: 1-128.

Williams R, Moyse J. 1988. Occurrence, distribution and orientation of Poecilasma kaempferi Darwin (Cirripedia: Pedunculata) epizoic on Neolithodes grimaldi Milne-Edwards and Bouvier (Decapoda: Anomura) in the North-East Atlantic. Journal of Crustacean Biology 8: 177-186.

Received: 20 November 2007

Accepted: 9 June 2008

Published online: 16 April 2009

Editor: R.W.M. van Soest 
